\title{
Internet Thinking and Reengineering Strategy of Traditional Tourism Enterprises
}

\author{
Xinwei $\mathrm{Su}$ \\ College of International Business \\ Liming Vocational University \\ Quanzhou, China 362000 \\ Faculty of International Tourism and Management \\ City University of Macau \\ Taipa, Macau 999078
}

\begin{abstract}
Since the rise of "Internet plus tourism" to the national strategic level, the integration of tourism industry and the Internet has brought about disruptive changes to the traditional tourism industry. Starting from this background, this paper researches the study situation on the integration of Internet and tourism enterprises at home and abroad, analyzes the influence of Internet on industries, especially traditional tourism enterprises, and analyzes the present situation and future trend of the development of Internet tourism industry, and discusses the reengineering strategy of traditional tourism enterprises based on Internet thinking.
\end{abstract}

Keywords-internet thinking; traditional enterprise; reengineering strategy

\section{INTRODUCTION}

In August 2015, the State Council issued several opinions on further promoting tourism investment and consumption, proposing to actively promote the development and growth of online tourism platform enterprises and to integrate the resources, elements and technologies of upstream and downstream and parallel enterprises. To form a new of tourism ecosphere, to promote the cross-industry integration of "Internet tourism", and to support qualified tourism enterprises to carry on Internet financial exploration, and to create a thirdparty payment platform for online tourism enterprises. The National Tourism Administration issued a circular on the implementation of the "Tourism Internet" Action Plan, which clearly states: by 2018 , online tourism investment accounts for $10 \%$ of the national tourism direct investment, and online tourism consumption expenditure accounts for $15 \%$ of the national tourism consumption expenditure. By 2020, all fields of tourism have been integrated with the Internet. "Internet Tourism" has become a new growth point of tourism industry in China.
In The Structure of Scientific Revolutions, Thomas Kuhn, a prominent American philosopher of science, argues that any great change will lead to new thinking, new concepts and new paradigms which will change the human's way of existence and way of life, and then will change human's idea, way of thinking and behavior mode [1]. Therefore, the popularization of the Internet inevitably brings about the change of the mode of human thinking, and of course, it promotes the change of the thinking paradigm of the tourism enterprises. Tourism is a modern service industry closely related to people's life. Its products, type of operation and business models are all influenced by the Internet. Therefore, traditional tourism enterprises cannot stay in the original traditional thinking principle, and must follow the wave of change and change the way of thinking to cater to the development of the Times.

\section{LITERATURE REVIEW}

The author uses the China National Knowledge Infrastructure (CNKI) database as the data source, and "Internet" and "tourism" as the search terms for synthesis search. The results are shown in Fig. 1 below. The first article that brought tourism and internet together is Yang Nanyou's The Internet and Tourism Business Opportunities in 1998 However, this article was more about the introduction to the marketing of tourism products on the Internet and had hardly talked about the integration of tourism and Internet. The real study as a research topic is The Marketing Thinking of Tourism Hotel Industry in the Internet Age written by Guo Jianying in 2001. Since then, the topic of "Internet and tourism" has gradually entered the research category of scholars. 


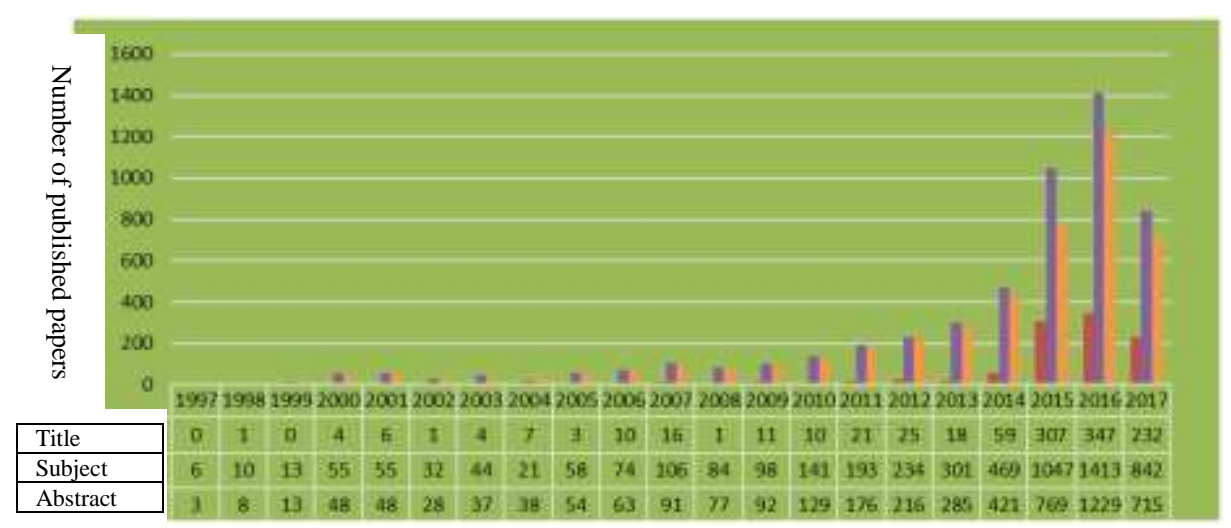

Fig. 1. Article search with search terms of "Internet" and "tourism"

At the same time, the author conducted researches by title, subject, keyword and full text respectively, and the results are shown in Table I below. As can be seen from the table, although the Internet and tourism are widely mentioned in numerous articles (mentioned in a total of 377,173 articles at the same time), there are only 1,080 literatures with the title of Internet and tourism, and nearly half of them are news reports. That is to say, the research on "Internet + tourism" is still more on the surface, and there are few in-depth studies.
Note: the data of 2017 up to October 31, 2017

TABLE I. LITERATURE RETRIEVAL STATISTICS OF "INTERNET" AND "TOURISM"

\begin{tabular}{|c|l|l|l|l|l|}
\hline Source & Title & Subject & Abstract & \multicolumn{1}{|c|}{ Keywords } & \multicolumn{1}{|c|}{ Full Text } \\
\hline Newspaper & 518 & 518 & - & - & 94435 \\
\hline Journal & 515 & 3386 & 3173 & 20 & 158575 \\
\hline Degree & 39 & 1249 & $\begin{array}{l}\text { (Doctorate } \\
\text { (D1) }\end{array}$ & 3 & $\begin{array}{c}118868 \\
\text { (Doctorate } \\
12105)\end{array}$ \\
\hline Meeting & 8 & 72 & 78 & - & 5295 \\
\hline Total & 1080 & 5225 & 4551 & 23 & 377173 \\
\hline
\end{tabular}

Since the "Internet + tourism" was promoted to the national strategy level in 2015, this topic has become a research hotspot in the tourism industry (see Table I). After analyzing 515 articles entitled "Internet" and "tourism", the author found that the main research keywords focus on "Internet", "mobile Internet", "tourism", "tourism industry", etc., and there are very few articles on the research of tourism enterprises and there are scarcely any researches on innovation and development strategy after the integration of Internet and tourism. See Fig. 2

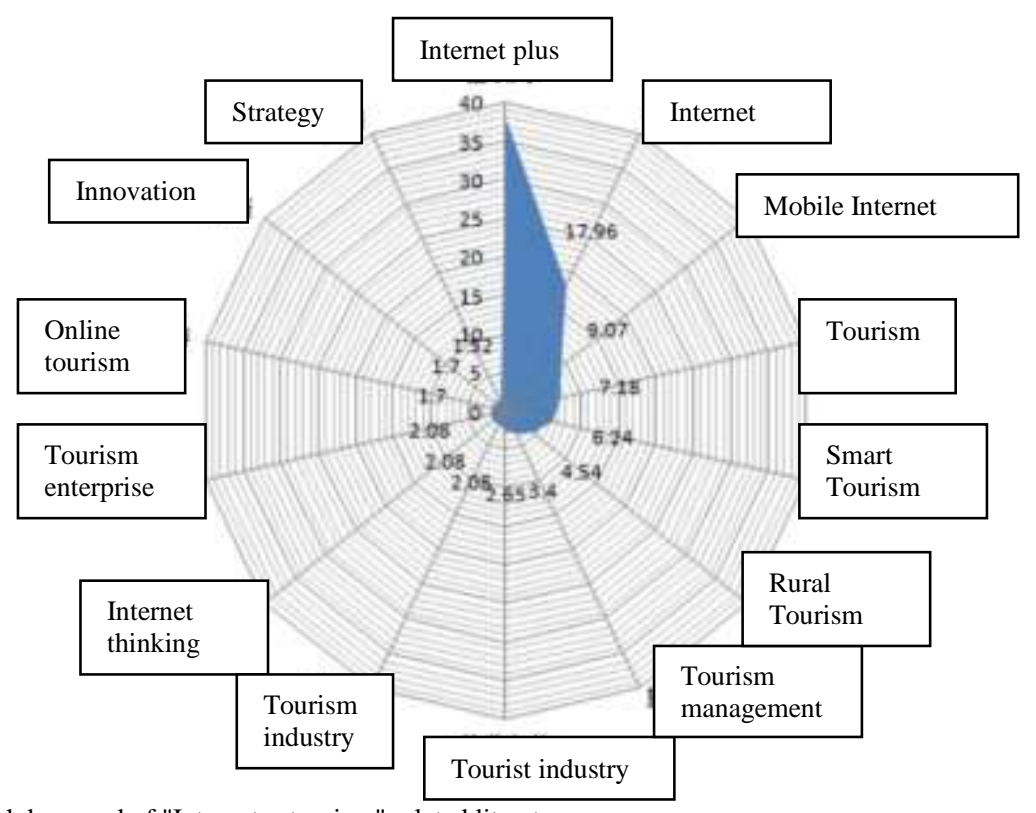

Fig. 2. Distribution diagram of research keyword of "Internet + tourism" related literatures. 
In terms of specific subject research, Zhang Tianwen and Wu Mingyuan take the internet blogs as research objects, using the grounded theory to conduct a study on the form of the happiness of tourists, and found that blog has become one of the main channels for tourists to express their travel satisfaction [2]; $\mathrm{Xu}$ Jinhai and Wang Jun studied the integration of "Internet plus" and tourism industry, and proposed the reform and upgrade strategy of tourism industry in the Internet era [3]; Zhang Chaozhi and You Wang take Huangshan mountain as an example to study the influence of Internet on the marketing of tourism destination, and found that during the tourism destination marketing process the dominant position of tourists is strengthened and the monopoly position of tourism intermediary is weakened [4]; Yang Yanfeng believes that the Internet has become a major driving force in the integration of tourism industry [5]; Bao Fuhua and Li Ling et al. take Ctrip as the study object to discuss the business model of Internet tourism enterprises from five aspects: tourism value proposition, tourism value chain, tourism marketing, tourism service management and profit model of tourism enterprises [6]; Li Heng and Quan Hua discussed the future trend of Internet tourism finance, and believed that the construction of Internet tourism finance business ecosystem, collectivization development, product design contextualization and asset securitization is the future development trend of Internet tourism finance [7]; DUAN. H $\mathrm{Y}$ takes rural tourism as an example to explore the construction of rural tourism industry chain based on the new model of Internet and cross-border integration [8]; it is worth noting that the Tourism Tribune has published two issues of special columns of the Chinese Tourism Development Viewpoint - the Change in Tourism Caused by the Internet in the 5th and 6th issues of 2016 respectively. The column, hosted by Zhou Lingqiang, invited 23 experts and scholars from the industry to discuss together and publish 14 articles on the topic of Internet and tourism, which discussed the integration of the Internet and tourism respectively in aspects such as the strategic reform, tourists travelling way, tourist behavior characteristics, influence of the industrial development, tourism education, five-force competition model of tourism industry, smart tourism, tourism new pattern and innovation of service system [9-10]. From the perspective of research and the aspects involved, it can be seen that the scholars focus more on the industrial level for the "Internet + tourism", who didn't pay enough attention to how the traditional enterprises in the tourism industry can carry out enterprise reengineering to better cope with the challenges brought by the Internet.

The development of Internet in foreign countries is much earlier than that of our country, and the time for the application of Internet technology in the tourism industry is earlier than that of our country. Back in the 1960s, American Airlines and IBM jointly developed the world's first web-based airline electronic ticketing system. Then later the airlines and travel agencies began to work together to make airline ticket booking extended to travel agents [11]; then the hotel also began to follow up, and began to develop hotel reservation and valueadded services, etc. [12]; the internet-based tourism marketing developed on this basis has become the first topic of Internet tourism research [13]; slightly different from China, in the study of Internet and tourism abroad, more attention is paid to how tourism enterprises can attract more tourists through the Internet and provide better services for them [14], such as research on the design of tourism website page [15], research on the function setting of tourism website [16]. In the study of the pricing model adopted to the tourists, the researchers found that the tourism enterprises usually adopt Merchant mode and Agency mode, that is, customer bids and quick transactions, which are generally interpreted as the transaction mode where the consumer gives the price and attribute of the commodity, and the enterprise decides whether to accept such conditions and provide the service [17]; in the macro aspect, Sahut J M discusses the pricing strategy of the tourism industry from the Internet [18].

It can be found throughout the domestic and foreign research that, the domestic research on Internet and tourism focuses more on the macro level of the industry, such as the influence of Internet on tourism industry, the integration of Internet and tourism industry and the future of Internet and tourism. But the researches abroad focus more on the micro level such as marketing and integration of tourism enterprises under Internet technology. However, the timely discussion of the Internet has certain research value to the reengineering strategy of traditional enterprises.

\section{THE INFLUENCE OF INTERNET ON TOURISM INDUSTRY}

Tourism is an important indicator of the improvement of people's living standards. According to the statistics of the National Tourism Administration, 4.44 billion domestic trips and 260 million inbound and outbound trips were made in China in 2016 with total tourism revenue of RMB 469 million yuan. China's tourism has developed into the middle and advanced stage of mass tourism. According to the latest 2016 Global Tourism Economic Report released by TripAdvisor, the world's largest review website, the mobile level of Chinese tourists ranks first in the world. According to the Statistics Report on the Development of Internet in China released by China Internet Network Information Center, China has 731 million Internet users including 695 million mobile Internet users. In the future, the Internet will continue to influence the development of China's tourism industry.

\section{A. Internet Thinking}

The Internet has been around for nearly half a century, and it has penetrated into every area of people's life. However, the Internet thinking was first proposed as a way of thinking by $\mathrm{Li}$ Yanhong in 2011. What is Internet thinking? Internet thinking refers to the way of thinking that can make full use of the spirit, value, technology, method, rules and opportunities of the Internet to guide, process and innovate the life and work [19]. Internet thinking is a diversified thinking, integrating traditional industries and fields with Internet technology and ideas. Internet is not only a technology and tool, equipment updating and technology upgrade alone doesn't bring qualitative change to the enterprises, instead, they should use Internet thinking to change the business philosophy and change the way of thinking. "Internet plus" is not a simple superposition and crossover between online and offline, but a combination with the characteristics of the industry to seek the 
development opportunities under the new market in collision and integration [20].

\section{B. The Internet Has Changed the Way Tourism Enterprises Operate}

The business model of traditional tourism enterprise has the disadvantages of the slow pace, tedious work content, long work process and no effective simplification, under which the enterprises have low working efficiency, high operating cost and poor tourist satisfaction. With the popularization of the Internet, traditional enterprises relying on information asymmetry will be eliminated by the market, and the intermediary functions of travel agents and tour wholesalers will be replaced by online travel network platforms, that is to say the Internet has made the price of product more transparent [21]. In addition, the Internet has made it harder for companies to maintain public relations, the tourists can make various comments on the service of tourism enterprises with the help of online platforms, which will seriously affect the marketing of enterprises.

\section{The Internet Has Changed the Consumption Behavior of Tourists}

In the traditional tourism market, the tourists have very few choices. Tourists need to pay more time and money to learn more information about tourism, and the source of information is single. After the integration of Internet and tourism, tourists get more information and have more choices in buying tourism products, and the combination of all kinds of elements of tourism is also more abundant. And most importantly, the price is more preferential without intermediary business. In addition, the interaction between tourists and tourism enterprises is more convenient and more frequent, which is very helpful for tourism enterprises to provide personalized service, and also improves the satisfaction of tourists.

\section{The Influence of the Internet on Managers}

The Internet's influence on the tourists is mainly reflected in terms of convenience and timeliness, and it is more convenient for the managers to learn about the information of tourists and obtain the employees' dynamics, which can help the managers to anticipate relevant information and make the corresponding management decisions, which greatly improve the effect of the management. The administrative departments can also master the real-time dynamic of the industry through Internet technology, such as the command platforms and big data centers set up by the National Tourism Administration and some provincial tourism administrations. The management of tourism destination is becoming more and more close to the needs of tourists, for example, the management department of the scenic area, by monitoring the current number of tourists in the scenic area, can timely take corresponding measures to avoid the tourists exceeding the capacity of the scenic area.

\section{CURRENT SituATION AND DEVELOPMENT TREND OF INTERNET TOURISM INDUSTRY}

\section{A. Current Situation}

\section{1) General situation}

In May 2017, the 2016 China Tourism Investment Report released by the National Tourism Administration shows that the total investment of tourism exceeded RMB 1 trillion yuan, while the investment of online tourism exceeded RMB 100 billion yuan in China in 2016. In 2015, online travel has formed a market of hundreds of billions. In the third quarter alone, the transaction reached RMB 122.23 billion yuan, up $18 \%$ from the previous quarter. After the State Council and the National Tourism Administration issued relevant documents on supporting the Internet + tourism, many provinces with rich tourism resources have launched Internet tourism development plans in the light of the booming Internet tourism. It can be seen that Internet + tourism has been effectively implemented in the local area, and the integration of tourism industry and Internet has become an irresistible trend. Although the current Internet tourism in China is well developed, compared with foreign countries, the foundation of China's Internet tourism is still relatively weak, which is currently in the special development period of informatization, e-commerce and digitalization [22].

\section{2) Industry status}

Although the integration of the Internet and tourism is a major trend, the Internet travel companies have emerged like bamboo shoots in recent years, and the competition throughout the whole market is extremely fierce. According to statistics and rankings in China Webmaster website, by the end of October 2017, a total of 1845 Internet travel enterprises in China are involved in six elements of tourism, namely, food, shelter, transportation, travel, shopping and entertainment. In addition to the original travel e-commerce giants (Ctrip, Qunar and Tuniu), the major Internet enterprises, such as Baidu, Ali, Jingdong and so on, have also entered into the tourism industry and are among the forefront of the industry. The cultural tourism industry of Wanda Group and HNA Tourism Group also have started to lay out the online travel business, which will continue to increase the impact on the tourism industry in the future. Based on the statistical data released by Zhongzheng Zhixin (Beijing) Economic Consulting Co., Ltd, only in 2016, 27 (see Table II) "Internet + Catering" enterprises closed down, and 24 (see Table III) "Internet + Tourism" enterprises closed down. The average time from the establishment of a company to its failure is less than 4 years, and even many companies have suffered losses since the beginning and have not achieved profitability. From the analysis of the company's main business, it can be found that most of the enterprises are engaged in tourism e-commerce platform or information sharing platform, but they do not have their own products. 
TABLE II. L LIST OF “INTERNET + CATERING” ENTERPRISE FAILURES IN $2016^{1}$

\begin{tabular}{|c|c|c|c|c|c|c|c|}
\hline $\mathbf{S} / \mathbf{N}$ & Item Name & $\begin{array}{c}\text { Date of } \\
\text { Establish } \\
\text { ment }\end{array}$ & Main Business & $\mathbf{S} / \mathbf{N}$ & $\begin{array}{l}\text { Item } \\
\text { Name }\end{array}$ & $\begin{array}{c}\text { Date of } \\
\text { Establishme } \\
\text { nt }\end{array}$ & Main Business \\
\hline 1 & $\begin{array}{l}\text { Fanshigang } \\
\text { Waimai }\end{array}$ & 2009.2 & $\mathrm{O} 2 \mathrm{O}$ take-out website & 15 & Wubengou & 2013.1 & $\begin{array}{l}\text { Vertical type food e-commerce } \\
\text { website }\end{array}$ \\
\hline 2 & Xpfood & 2009.3 & $\begin{array}{l}\text { Take-out food ordering } \\
\text { service website }\end{array}$ & 16 & Hicoffee & 2013.1 & Focus on urban coffee community \\
\hline 3 & Anyway & 2009.9 & $\begin{array}{l}\text { Take-out order service } \\
\text { website }\end{array}$ & 17 & Sixiangshi & 2013.4 & $\begin{array}{l}\text { H5 mobile application, recommend a } \\
\text { nearby restaurant }\end{array}$ \\
\hline 4 & $\begin{array}{l}\text { Cengfan } \\
\text { Website }\end{array}$ & 2011.11 & $\begin{array}{l}\text { Specialize in take-out } \\
\text { website }\end{array}$ & 18 & $\begin{array}{l}\text { Guofen } \\
\text { Kitchen }\end{array}$ & 2013.5 & $\begin{array}{l}\text { Online ordering and catering service } \\
\text { for white collar }\end{array}$ \\
\hline 5 & $\begin{array}{l}\text { Haochilao } \\
\text { Delicacy } \\
\text { Website }\end{array}$ & 2011.12 & $\begin{array}{l}\text { O2O catering platform in } \\
\text { Wuhan }\end{array}$ & 19 & Ufanju & 2013.6 & $\begin{array}{l}\text { APP, create dinner and invite friends } \\
\text { to participate }\end{array}$ \\
\hline 6 & YiWaiMai & 2011.3 & $\begin{array}{l}\text { Take-out food ordering } \\
\text { net }\end{array}$ & 20 & Haohaochi & 2013.6 & $\begin{array}{l}\text { Short video food sharing and } \\
\text { guidance application }\end{array}$ \\
\hline 7 & $\begin{array}{l}\text { Feimao Meals } \\
\text { Delivered }\end{array}$ & 2011.4 & $\begin{array}{l}\text { Mobile terminal food } \\
\text { reservation platform }\end{array}$ & 21 & $\begin{array}{l}\text { Aunt } \\
\text { Kitchen }\end{array}$ & 2013.6 & $\begin{array}{l}\text { Food production and surrounding } \\
\text { distribution }\end{array}$ \\
\hline 8 & Dingjiuyan & 2011.6 & $\begin{array}{l}\text { Banquet distribution } \\
\text { website }\end{array}$ & 22 & Paiduitong & 2013.7 & $\begin{array}{l}\text { Restaurant queue number mobile } \\
\text { application }\end{array}$ \\
\hline 9 & Kuaile 777 & 2011.7 & $\begin{array}{l}\text { Real time food ordering } \\
\text { platform }\end{array}$ & 23 & E Shi e Ke & 2013.9 & $\begin{array}{l}\text { LBS food and beverage sharing and } \\
\text { reservation service }\end{array}$ \\
\hline 10 & $\begin{array}{l}\text { Fengyi } \\
\text { Tianshi }\end{array}$ & 2011.7 & $\begin{array}{l}\text { Mobile phone food } \\
\text { ordering system }\end{array}$ & 24 & $\begin{array}{l}\text { Zhulin } \\
\text { Panda }\end{array}$ & 2013.9 & $\begin{array}{l}\text { Free brand online fast food } \\
\text { reservation }\end{array}$ \\
\hline 11 & Caipu Net & 2012.10 & $\begin{array}{l}\text { Delicacy information } \\
\text { service }\end{array}$ & 25 & $\begin{array}{l}\text { Daie } \\
\text { Breakfast }\end{array}$ & 2014.11 & $\begin{array}{l}\text { Breakfast booking platform based on } \\
\text { the Internet }\end{array}$ \\
\hline 12 & $\begin{array}{l}\text { QDianWaima } \\
\text { i }\end{array}$ & 2012.12 & $\begin{array}{l}\text { Mobile phone ordering } \\
\text { take-out service. }\end{array}$ & 26 & $\begin{array}{l}\text { Mr. } \\
\text { Zhanban }\end{array}$ & 2014.11 & Semi fresh-cut vegetables $\mathrm{O} 2 \mathrm{O}$ \\
\hline 13 & Dingcantong & 2012.9 & $\begin{array}{l}\text { Online food ordering } \\
\text { platform }\end{array}$ & 27 & $\begin{array}{l}\text { Ximu } \\
\text { Liangban }\end{array}$ & - & Focus on cold noodle take-out \\
\hline 14 & $\begin{array}{l}\text { Pinpin } \\
\text { Delicacy }\end{array}$ & 2013.1 & Provide food information & & & & \\
\hline
\end{tabular}

TABLE III. LIST OF “INTERNET + TOURISM” ENTERPRISE FAILURES IN $2016^{2}$

\begin{tabular}{|c|c|c|c|c|c|c|c|}
\hline $\mathbf{S} / \mathbf{N}$ & Item Name & $\begin{array}{l}\text { Date of } \\
\text { Establis } \\
\text { hment }\end{array}$ & Main Business & $\mathbf{S} / \mathbf{N}$ & Item Name & $\begin{array}{c}\text { Date of } \\
\text { Establish } \\
\text { ment }\end{array}$ & Main Business \\
\hline 1 & $\begin{array}{l}\text { Puhui Business } \\
\text { Website }\end{array}$ & 2002.7 & $\begin{array}{l}\text { Air tickets, hotels, tourism and other } \\
\text { business }\end{array}$ & 13 & 1688 ticket & 2013.1 & $\begin{array}{l}\text { Tourist attraction ticket purchase } \\
\text { and wholesale platform }\end{array}$ \\
\hline 2 & Lvfutong & 2010.1 & $\begin{array}{l}\text { Full-course tourism online service } \\
\text { platform }\end{array}$ & 14 & Youjiaoyin & 2013.1 & $\begin{array}{l}\text { Scenic spot sharing and } \\
\text { personalized recommendation } \\
\text { sites }\end{array}$ \\
\hline 3 & Juzhai Website & 2011.7 & $\begin{array}{l}\text { A platform that look for partners to go } \\
\text { on an outing }\end{array}$ & 15 & $\begin{array}{l}\text { Good Chinese } \\
\text { tour guide }\end{array}$ & 2013.1 & $\begin{array}{l}\text { Tourism service industry e- } \\
\text { commerce website }\end{array}$ \\
\hline 4 & $\begin{array}{l}\text { Jiaoya Travel } \\
\text { Website }\end{array}$ & 2011.7 & Route lookup, design and sharing & 16 & Aizhouyou & 2013.1 & $\begin{array}{l}\text { Nearby tour products e- } \\
\text { commerce website }\end{array}$ \\
\hline 5 & $\begin{array}{l}\text { Na Travel } \\
\text { Website }\end{array}$ & 2012.10 & $\begin{array}{l}\text { Information, question and answer, } \\
\text { shopping guide }\end{array}$ & 17 & Journey help & 2013.1 & $\begin{array}{l}\text { LBS technical instant Q\&A } \\
\text { platform }\end{array}$ \\
\hline 6 & Jelly Trip & 2012.11 & $\begin{array}{l}\text { A one-stop overseas tour guide and } \\
\text { translation }\end{array}$ & 18 & Koudai Trip & 2013.1 & Provide mobile travel guide \\
\hline 7 & Zhaohaowan & 2012.1 & Surrounding tourism service website & 19 & $\begin{array}{l}\text { Wander South } \\
\text { Luogu Lane }\end{array}$ & 2013.4 & $\begin{array}{l}\text { Provide tourism services related } \\
\text { South Luogu Lane }\end{array}$ \\
\hline 8 & Owntrip & 2012.4 & $\begin{array}{l}\text { Specialize in outbound free travel } \\
\text { service }\end{array}$ & 20 & $\begin{array}{l}\text { Thai Aiwan } \\
\text { TripWebsite }\end{array}$ & 2013.4 & A Thailand travel community \\
\hline 9 & Tubogo Trip & 2012.8 & $\begin{array}{l}\text { Recommended tour product shopping } \\
\text { platform }\end{array}$ & 21 & Hotel Duoduo & 2013.5 & $\begin{array}{l}\text { Mobile phone inquiry, booking } \\
\text { hotel services }\end{array}$ \\
\hline 10 & Xingyuehui & 2013.10 & $\begin{array}{l}\text { Private high-end customized travel } \\
\text { platform }\end{array}$ & 22 & Camel Grass & 2013.7 & Travel sharing and route services \\
\hline 11 & $\begin{array}{l}\text { Qilvlv } \\
\text { surrounding } \\
\text { tour }\end{array}$ & 2013.11 & $\begin{array}{l}\text { City surrounding tour and product } \\
\text { shopping guide }\end{array}$ & 23 & Hiking Website & 2013.7 & $\begin{array}{l}\text { Provide tourism information } \\
\text { service in Wenzhou }\end{array}$ \\
\hline 12 & Tiehe Software & 2013.11 & Local guide travel butt & 24 & $\begin{array}{l}\text { Zaigezaiwu } \\
\text { Trip Website }\end{array}$ & 2014.1 & $\begin{array}{l}\text { The main service is self-service } \\
\text { travel of home exchange. }\end{array}$ \\
\hline
\end{tabular}

${ }^{1}$ Data source: Zhongzheng Zhixin (Beijing) Economic Consulting Co., Ltd 2016.12.1

${ }^{2}$ Data source: Zhongzheng Zhixin (Beijing) Economic Consulting Co., Ltd 2016.12.1 


\section{B. Development Trend}

\section{1) Diversification of business models}

For the $\mathrm{O} 2 \mathrm{O}$ mode, Alibaba, a typical representative of the current e-commerce enterprises, Ma Yun, chairman of board of directors of the company, said: pure e-commerce has died, and the future e-commerce must be a combination of e-commerce and physical stores. Similarly, the tourism enterprises, which are mainly engaged in physical stores, have started to plan the online business. For example, Traveling Bestone has more than 5,000 physical franchise stores throughout all major counties and cities of provinces and regions. It has basically completed the offline overall layout, and also has been working on the online business currently. As the leading enterprise of the online tourist agent, the business of Ctrip almost covers the six main elements of tourism. In 2016, Ctrip achieved annual net revenue of 19.2 billion yuan, increasing by $76 \%$ year on year, and the operating profit ratio was $10 \%$, which was the highest performance in all tourism Internet enterprises. Currently, from Ctrip's seeking the expansion of offline channels, it can be seen that the online and offline channel model is becoming the development direction of the tourism market.

For the B2C mode, this mode includes the OTA (Online Travel Agent) mode and online platform mode. The OTA model refers to the process that the traditional travel agency establishes its own website and sells its travel products online. The online platform is more like an online supermarket, but it does not have its own products and only provides a transaction platform for enterprises and customers. From the traditional tourism enterprises own businesses, the OTA model is more suitable for the transformation of its business.

For the $\mathrm{C} 2 \mathrm{C}$ mode, the Internet is not only open to tourism enterprises, but also to users. Currently, an increasing number of users have started to change from a single user role to a dual role in user and commercial tenant. In other words, the user provides services for tourists by using the Internet in the idle state of resources and earn a certain amount of money, such as individual tour guide, overseas shopping representative, food recommendation and so on, although many of these businesses are still in a non-standard state, their development has become a trend, and it is just a matter a time before they are standardized. Therefore, tourism enterprises must also consider how to cope with the competition in this market segment.

The C2B mode is also called UGC (User Generated Content) mode. It is a mode that the customers release the demand portfolio to the network (OTA or online platform) based on their needs, and tourism enterprises make quotation based on their own demand portfolio for customers to purchase. With increasingly strong diversification and individuation of tourists' demand, the future UGC model will inevitably become the main form to test the traditional tourism enterprises.

\section{2) Smart tourism is inevitable}

The mode of Internet + tourism is only the primary stage, and it will be bound to move forward in the direction of smart tourism. At present, the traditional enterprises pay more attention to how to attract more tourists upon their using of the Internet. Ultimately, what they are concerned about is the enterprises' benefits, and the focus is still on the enterprise itself. While the smart tourism is different, it requires enterprises to pay attention to the various elements of the tourism industry, such as tourism resources, tourism economy, tourism activities, tourism consulting, tourists and so on, and actively capture customer needs through the Internet and cloud computing technologies, so as to provide services to meet their needs. That is to say, the focus is still on the tourists, and only by paying attention to the needs of the tourists can make the enterprise invincible.

3) The development of tourism industry chain moves forward to industrial network

After posting the customer information, tourism products, advertisement marketing and other elements on the Internet, whether it is the tourism manufacturer, tourism wholesaler, travel agent, tourist, or other stakeholder, they can gain value from it. Therefore, Internet tourism has further deepened the industrial chain, and the form of tourism industry chain has been reconstructed and upgraded, and it transforms from a single value chain to a multidimensional value network, which increases the added value of the tourism industry and form the value source of the entire tourism industry.

\section{THE STRATEGY OF INTERNET REENGINEERING FOR TOURISM ENTERPRISES}

\section{A. Repositioning of Enterprises}

Based on their own business type, market status, enterprise scale and other status, combined with the current development status of the "Internet + Tourism" industry, the traditional enterprises must reposition themselves. Currently, among the Internet tourism enterprises, some of them are comprehensive, that is, aiming at the six elements of food, shelter, transportation, travel, shopping and entertainment, and some of them provide services for the individual or several elements. Enterprises should analyze their own advantages and industrial value chains to determine the direction of their transformation and upgrading. After all, since the advent of Internet technology, numerous tourism and other related enterprises have failed or even closed down because of their excessive dependence on the Internet or improper use of Internet technology. Therefore, the tourism enterprise itself must be able to scientifically use the Internet and related technologies and have a strong ability to control the tourism market.

\section{B. Enrich the Offline Product Line}

Owning enough product lines is the premise to attract customers for an enterprise. The Internet is ultimately a tool, and the development of the industry will inevitably depend on products. It is impossible for China's e-commerce industry to achieve such impressive achievements without a strong manufacturing industry. Similarly, tourism enterprises must enrich the offline products in the first while expanding the online promotion and sales. Regardless of which forum the traditional tourism enterprise positions itself upon coping with the Internet, it will necessarily enrich its product types. Only 
abundant product categories can attract enough flow, and the enterprise has room for profit and survival. "Online" is the quickest way for an enterprise to communicate with potential customers through the Internet. However, no matter how advanced the "online" is, the "offline" cannot be replaced, because the travel experience can never be obtained through virtual network.

\section{Full Excavation of Enterprise Data Resource}

Now many companies have followed the trend seriously, and deliberately chased new technologies and fashions, such as cloud computing, big data, and the Internet of Things. Of course, these new technologies do bring great impact to the industry, but not all companies can use these technologies and data well. It is not a problem for traditional tourism enterprises to get data information, such as travel notes, logs, micro-blog, etc., but it is very difficult to get data such as consumption data, travel path and location information. Besides, many data analysis purposes and variables design of many platforms are not customized for tourism enterprises, and traditional tourism enterprises can not directly use them. Even if these data are acquired, they are of little significance. Therefore, when chasing big data, enterprises should first start with the mining of its own small data, analyze customer needs, customer satisfaction, customer revisit rate, so that tourists can upgrade from "first time customer" to "customer's turn back" to "returned customer", and obtain new business opportunities from it.

\section{Reserves of Related Talents for Enterprises}

The competition of enterprises is ultimately for talents. In the current traditional tourism enterprises, the decision-making levels are mostly born in the 1960s, and the management and executive levels are mostly born in the 1970s, while the users are mostly born in the 1980s and 1990s, additionally the young who born after the year 2000 have also joined the users, which should not be belittled. Whether decision makers and managers can accurately grasp the needs of users and whether they can adapt to their propositions of consumption and their ways of thinking will determine whether they can be accepted by them. At present, most of the traditional tourism enterprises have marketing capabilities but not have Internet thinking, while that have Internet technology do not master marketing. Therefore, it becomes the key problem to be solved in the business reengineering of traditional tourism enterprises whether they can adequately control the complex talents of tourism and Internet or not.

\section{E. The Omnichannel Strategy of Tourism}

Traditional tourism companies basically rely on the provision of offline tourist products or services, but the Internet has virtually eliminated the advantages of traditional offline products and services, and various new models have been emerged under the impact of Internet, so traditional enterprises must actively open up various channels when maintaining their offline sales, so as to achieve the omnichannel and barrier-free contact between enterprises and tourists (see Fig. 3). All channels have their own advantages, e.g. the intimacy of offline customer service is unmatched on the line. Omni-channel strategy require enterprise to have complete basic channels, and also to provide complete information, that is the information obtained by each tourist in various channels should be accordant, and finally it requires the enterprises to have complete functions of customer service, that is, regardless of offline or online, enterprises should meet the demand of consumers.

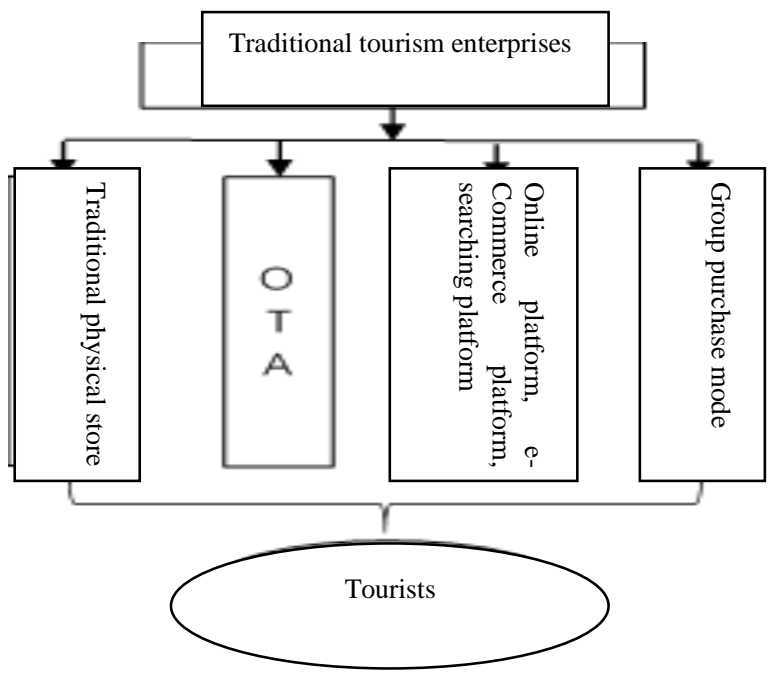

Fig. 3. The omni-channel marketing model of traditional enterprises

\section{F. Traditional Tourism Enterprises Should Integrate Them into Smart Industry}

The smart industry is currently the tuyere industry based on the Internet, the Internet of things, and information technology. It mainly includes three functions: optimizing policy, prospering industry and benefiting people. Tourism belongs to the people's livelihood industry, and it should be integrated into the smart industry, especially the construction of smart cities. In addition, the combination of the Internet and tourism has hastened the production of a lot of new tourism types, especially in the four elements of food, housing, transportation, and travel. Traditional enterprises should take the direction of smart tourism, actively integrate them into smart tourism, and follow the development of the industry.

\section{CONCLUSION}

The integration of the Internet and the tourism industry has subverted the traditional tourism industry, and the governments from the country level to the region level all are actively promoting the integration of the two sides. Traditional tourism companies, as the earliest and most important component of the tourism industry, must solve an important issue that traditional tourism companies will be destructed by a new wave of industry or will actively respond to industrial changes and resurrect through the strategy of transformation and upgrading and reengineering. 


\section{REFERENCES}

[1] Yang Dejin, Xu Hong. Seven Strategic Changes of the New Kinetic Energy of the Internet Spurring Tourism [J]. Tourism Journal, 2016, 31(05): 1-3.

[2] Zhang Tianwen, Wu Mingyuan. The Formation of Tourist Happiness Based on Theory: Taking Internet Travel Blog Text as an Example[J]. Tourism Journal, 2014, 29(10):51-60.

[3] Xu Jinhai, Wang Jun. Research on the Integration of Tourism Industry in the "Internet+" Era[J]. Research on Financial and Economic Issues, 2016, (03): 123-129.

[4] Zhang Chaozhi, You Wang. Influence of the Internet on Distribution Channels of Tourist Destinations: A Case Study of Huangshan Mountain[J]. Tourism Journal, 2012, 27(03):52-59.

[5] Yang Yanfeng. Internet Technology Has Become the Main Driving Factor for the Integration of Tourism Industry and New Type of Business[J]. Tourism Journal, 2012, 27(09):7-8.

[6] Bao Fuhua, Li Ling, Zheng Qiuchan. Analysis and Study on the Business Model of Internet Tourism Enterprises: Taking Ctrip as an example [J]. Ecological Economy, 2013, (03): 156-159+165.

[7] Li Heng, Quan Hua. Research on Internet Tourism Finance and Its Future Trends [J]. Ningxia Social Sciences, 2016.6, 110-115

[8] Duan H y. Study on the Reform of Rural Tourism Industry Chain based on the New Normal of Internet Plus and Cross-border Integration[J]. Boletín Técnico, Vol.55, Issue 11, 2017,386-392

[9] Commentary on China's Tourism Development - -- The InternetInduced Tourism Changes (I) [J]. Tourism Journal, 2016.5, 1-14

[10] Commentary on China's Tourism Development --- The Internet-Induced Tourism Changes (2) [J]. Tourism Journal, 2016.6, 1-16

[11] Dalli A, Bri S. Design of Electronic Ticket System for Smart Tourism[C]//Signal-Image Technology \& Internet-Based Systems (SITIS), 2016 12th International Conference on. IEEE, 2016: 490-492.

[12] Murthy M K, Heeramani E B, Nagaraj E B. HiFi Hotel Business \& Management with Computers \& Robots of 2024[J]. 2017.

[13] Leung X Y, Xue L, Bai B. Internet marketing research in hospitality and tourism: a review and journal preferences[J]. International Journal of Contemporary Hospitality Management, 2015, 27(7): 1556-1572.

[14] Standing, C., J. Tang-Taye and M. Boyer, The Impact of the Internet in Travel and Tourism: A Research Review 2001-2010[J]. Journal of Travel \& Tourism Marketing, 2014. 31(1): 82-113.

[15] Rodríguez-Molina M A, Frías-Jamilena D M, Castañeda-García J A. The contribution of website design to the generation of tourist destination image: The moderating effect of involvement $[\mathrm{J}]$. Tourism Management, 2015, 47: 303-317.

[16] Masron T, Ismail N, Marzuki A. The conceptual design and application of web-based tourism decision support systems[J]. Theoretical and Empirical Researches in Urban Management, 2016, 11(2): 64-75.

[17] Xiang Z, Magnini V P, Fesenmaier D R. Information technology and consumer behavior in travel and tourism: Insights from travel planning using the internet[J]. Journal of Retailing and Consumer Services, 2015, 22: 244-249.

[18] Sahut J M, Hikkerova L. The impact of internet on pricing strategies in the tourism industry $[\mathrm{J}]$. The Journal of Internet Banking and Commerce, 2014, 14(1): 1-8.

[19] Guo Jingyan. The Media Convergence Path of American Newspaper Industry and Its Enlightenment[J]. Cradle of Reporters, 2015, (07): 3435 .

[20] Sun Jian. "Internet+" era: New thinking on the Development of the Tourism Hotel Industry. Tourism Journal, 2015(07): 11-13

[21] Wang Kunxin, Shi Qingbin. Introspection and Thinking on Internet Tourism. Tourism Journal, 2016(06): 15-16

[22] Xiang Yucheng. Reflections on the Development of Tourism Industry in the Context of "Tourism + Internet." Tourism Journal, 2016 (05): 8-10. 